\title{
MAP OF RETURN OF SHARES AND VOLUME ACTIVITY TRADING OF COMPANIES IN INDONESIA ON THE PANDEMIC TIME OF COVID-19
}

\author{
Hersugondo \\ Management, Faculty of Economics and Business, Diponegoro University \\ Email: hersugondo@live.undip.ac.id \\ Abdul Karim \\ Management, Faculty of Economics and Business, Diponegoro University \\ Email: karimabdul18061998@gmail.com (corresponding author)
}

\begin{abstract}
Abdul Rouf
Economic Development, Faculty of Economics and Business, Diponegoro University

Email: abdulrouf.undip@gmail.com
\end{abstract}

Received: January 2021; Accepted: March 2021; Available online: July 2021

\begin{abstract}
This research was conducted to determine the impact of Covid-19 on the Company's stock returns and trading volume activity. The covid-19 pandemic event is important for research because it includes investor's assessment of the information generated in the capital market. This study was conducted to test the following hypotheses: before and after the Covid-19 pandemic was declared a national non-natural disaster, (1) there was a significant average change in the average abnormal return; (2) it is a significant average change in average trading volume activity. This research was conducted using event research methods. The sample for this study comes from 45 companies in the JII index. The analysis tool used is a regression with the SPSS. The descriptive statistic can be confirmed by calculating the standard deviation value. The result shows that the standard deviation range is 0.0002 to 0.03 , so the research tool could be described as data obtained is suitable to the measurement variable. The conclusions explain that the events before and after the declaration of the Covid19 outbreak as a national non-natural disaster have positive and a significant impact on the average abnormal return rate of stock activity and changes in trading volume activity.

Keywords : abnormal return; trading volume activity; Covid-19 pandemic; national nonnatural disaster.
\end{abstract}

\begin{abstract}
Abstrak
Penelitian dilakukan untuk mengetahui dampak Covid-19 terhadap return saham dan aktivitas volume perdagangan perseroan. Peristiwa pandemi Covid-19 penting untuk penelitian karena memuat penilaian investor terhadap informasi yang dihasilkan di pasar modal. Studi ini dilakukan untuk menguji hipotesis sebagai berikut : sebelum dan sesudah pandemi Covid-19 dinyatakan sebagai bencana non alam nasional, (1) terhadap perubahan rata-rata yang signifikan pada abnormal return; (2) terjadi perubahan rata-rata yang signifikan dalam aktivitas volume perdagangan rata-rata. Penelitian ini dilakukan dengan menggunakan metode penelitian peristiwa. Sampel penelitian Verasal dari 45 perusahaan yang ada di indeks JII. Alat analisis menggunakan regresi dengan bantuan aplikasi SPSS. Statistik deskriptif dapat dikonfirmasi dengan menghitung nilai standar deviasi. Hasil penelitian menunjukkan bahwa kisaran standar deviasi adalah 0,0002 sampai 0,03; sehingga alat penelitian dapat digambarkan sebagai data yang diperoleh sesuai untuk variabel pengukuran. Kesimpulan menunjukkan bahwa peristiwa sebelum dan sesudah pencanangan wabah Covid-19 sebagai bencana non alam nasional berdampak positif dan signifikan
\end{abstract}


terhadap rata-rata pengembalian abnormal trading saham serta perubahan aktivitas volume perdagangan.

Kata Kunci : pengembalian abnormal; aktivitas volume trading; pandemi Covid-19; bencana non alam nasional.

How to Cite: Hersugondo, Karim, A., \& Rouf, A. (2021). Map of Return of Shares and Volume Activity Trading of Companies in Indonesia on The Pandemic Time of Covid-19. Media Ekonomi dan Manajemen, 36(2), 156-169. doi: http://dx.doi.org/ 10.24856/mem.v36i2.1892.

\section{INTRODUCTION}

In 2020, the threat of the Covid-19 pandemic will shock the world. The pandemic resulted in more than 1.4 million confirmed cases also more than 83,000 death worldwide (Nicola et al., 2020). Due to the Covid-19 pandemic, financial markets have reacted tremendously. March 2020, US stock market touched circuit breaker mechanism four times in ten days. The japaneses stock market has fallen more than 20\% from Desember 2019. The main UK index FTSE fell by more than $10 \%$ on March 12, 2020 (Zhang et al., 2020).

It is feared that the government announcement about the Covid-19 Pandemic as a Non-Natural Disaster is feared to trigger an economic crisis and recession. Pandemic Covid-19 has the potential to destroy the live hoods of individuals, industries, businesses, and entire economies Laing, (2020). Covid-19 pandemic will deliver in the economic sector, especially it will cause a crisis in financial markets Goodell (2020). The financial market on the Indonesia Stock Exchange reacted by providing a strong response to this information. Governmentissued policies cause concern for company shareholders. For this reason, researchers make research sketches and partial equations to examine the role of pandemics in the financial sector. In this study also presented research that the impact of epidemics and pandemics in the past is as frightening as a large-scale event such as Covid-19, and its economic consequences.

The existing literature focuses on the cost of disease or the economic impact of disease caused by disease morbidity and mortality. H. Liu, Manzoor, Wang, Zhang, \& Manzoor, (2020) studying the spread of the SARS epidemic in Hong Kong, solve its economics impact, and obtain the greatest negative impact from consumers, because the short-term economic impact is largely affected by local consumers, tourism, and air travel-related services.

Del Guidice (2017), by observing the monthly flow and results during 20152016, evaluated 78 regional equity funds in African countries, and obtained the results of Ebola Virus and Arab Spring seriously affecting the flow of funds, controlling fund performance, expenditures, and market returns. Seeing the impact on the stock market, (Delisle, 2014), said the costs of the 2003 SARS pandemic caused the biggest loss in the Asian Financial Crisis, with an estimated GDP value of US\$3 trillion and a financial market value of US\$2 tillion in stocks. (Nippani \& Washer, 2006), studied impact of SARS in Canada, Hong Kong, Indonesia, China, Singapore, Philippines, Vietnam, and Thailand and other special administrative regions, and concluded that SARS just affects Chinese and Vietnamese Stock Market.

Macciocchi (2016), studied shortterm economic impact of Zika virus pandemic in Argentina, Brazil, and 
Mexico. M. Chen et al., (2007), used event research method for study impact of the SARS pandemic on efficiency of Taiwan's hotel stocks, and found that during the SARS pandemic, the stocks of 7 trading companies dropped sharply in 2008. Earning and stock prices.

X. Chen \& Chiang (2020) analyzed impact of the SARS epidemic on the longterm relationship in the total stock price index, and they also found that the pandemic has major impact on performance of Taiwan's biotech stocks. According Bai (2014), and Baker, Wirgler and Yuan (2012), investor may be pessimistics about the prospect of investing in specific market due to selling these market shares under the pandemic.

The stock market is intertwined and interdependent. Researchers found crossmarket conclusions during a critical period. Donadelli \& P.G, (2016), the trend of the stock market is becoming more and more relevant. Events such as the pandemic of infectious diseases may trigger negative fluctuations in investors sentiment, profoundly affecting their investment decision, and then affecting stock market price. Chen and Chiang (2020), studied the daily stock returns of 9 Asian Markets from 1996-2003 and found that there was high correlation among the sample Asian Countries during crisis. Shu (2010) found that Southeast Asian Market such as Malaysia, Vietnam, and Thailand have the highest degree of integration with China. Lucia \& B.A.O (2012), the global stock market becomes more and more dependent, and the crisis in 1 country will soon spread other countries. Zouaoui (2011), in countries that culturally more susceptible to herd activities also overreactions or country with low institutional participation, investor sentiment has a more obvious impact on the stock market.
An information is able to influence price determination in the capital market. Investment decision making by investors can be known by the presence of a signal from the information published as an announcement (Hartono, 2015). The Covid-19 pandemic will cause Covid-19 pandemic will cause investors to avoid huge losses by selling their shares. On the other hand, there are investors who speculate by selling stocks at the right time when the price shows a profit.

\section{LITERATURE REVIEW}

The market will react if an event contains information (Bernanke, 2010). If the market reacts to events, a significant abnormal return will be obtained (Gorton, 2009). Investment is an investment that is expected to generate additional funds in the future (Abraham, 1991). By understanding every investment risk, the investment can anticipate losses that can occur (Tachibana, 2018). In investment theory, one way to find out the answer to uncertainty due to an outbreak is to use the historical approach (Gatot, 2014). In making investment decisions, investors always try to minimize the various conditions that require an investor to decide what to do and what strategies are implemented so that he still gets a return (Tjiptono, 2011). Black Swan Event Theory reads "stock market returns respond to major events". Theory of Black Swan Events Theory refers to rare events that have a large impact, are difficult to predict and are beyond normal estimates and also cause a stir in the financial markets (Taleb, 2007). In the world of capital markets, if there is a Black Swan Event, it can be utilized by realizing profits if it rises rapidly and investing if it goes down (Rusdin, 2016). The Covid-19 outbreak was considered a negative signal by investors because this information made 
conditions in the capital market not conducive (Al-Wadhi, 2020).

\section{Hypothesis Development}

Relationship between Outbreaks with Average Abnormal Returns

WHO and public health officials act as mediators, communicating risk of an outbreak to investors and forming investors' views on the disease (Burns, 2011). Investor sentiment significantly affects the stock market (Lu, 2012). Engelberg, J.; \& Parsons (2011) shows that investment decision may affected by bad mood and anxiety. Investors who have information that the equilibrium price will reach a certain price level can buy certain securities and will later sell them at the equilibrium price and vice versa (Liu, 2020). Hendriswari (2017), the impact of the outbreak of avian Influenza virus on the stock returns and trading volume activities of livestock company on the Jakarta Stock Exchanges was studied. Results show that the differences in average abnormal stock returns beforeafter Avian Influenza Virus outbreak is determined to be a national disaster can be seen that the Avian Influenza Virus outbreak has an impact on the Stock Returns of Chicken Farms on the Jakarta Stock Exchange.

$\mathrm{H} 1$ : There is a significant average change in the average abnormal return (AR) of the company's shares before and after the announcement of the Covid-19 Pandemic as a National Non-Natural Disaster.

Relationship between Outbreaks with Average Trading Volume Activity

According to Shu (2010), the more active stocks are traded, the greater the trading volume activity. Wang (2013), investigated how infectious disease outbreaks affect the performance from biotech stock, showin Taiwan's biotechnology industry has obvious abnormal trading volume activity results due to infectious diseases. Ichev, R.; \& Marinic (2017), studied the geographic proximity the information disseminated by Ebola in 2014 and whether extensive media coverage has affected the price of US equity assets. Results show that impact on stock price is negative, and media local have reported significant impact on local trade. Impact is pronounced when the industry is unstable, and stocks are more volatile.

H2: Before and after the pandemic Covid19 was declared a "national non-natural disaster", the trading volume of stockactive companies changed significally.

\section{RESEARCH METHODS}

This type of research conducted using a statistical inferences approach and use a method of studying the events of the Covid-19 outbreak announcement as a National Non-Natural Disaster to analyze data and test hypotheses. Data source used in this research is auxiliary data. Data collection methods use are the non-partisan observation methods. The sample used is daily data from 45 listed companies in the JII index, with provisions 15 days before and 15 days after the announcement of the National Non-Natural Disaster.

\section{The Dependent Variable}

Dependent variables are stock price and trading volume activity from each industry. Stock price refer to investment that change over time (from time for time). Because price of stock used as research material is close to the price in Maret-Mei 2020. Stock income is the main goal of an individual or company's investment. In this method, measurement of stock returns will be used as dependent variable. 
Which formula is :

$$
\frac{R i, t=R_{i, t}-P_{i, t-1}}{P_{i, t}}
$$

For Information:

$\mathrm{R}_{\mathrm{i}, \mathrm{t}}=$ Current Return

$\mathrm{P}_{\mathrm{i}, \mathrm{t}} \quad=$ Current Stock Price

$\mathrm{P}_{\mathrm{i}, \mathrm{t}-1}=$ Share Last Period

Independent Variable

Rmt : Average Abnormal Return

TVA : Average Trading Volume Activity

\section{The Model of Data Analysis}

To test research and investigate relationship between outbreaks with return also trading volume activity, following multiple regression are used:

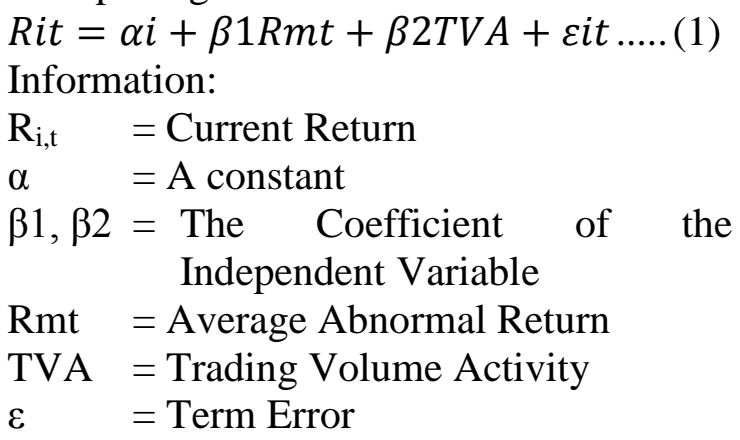

\section{RESULT AND DISCUSSION}

Result

Descriptive statistic can be confirmed by calculating the standard deviation value. Table 1 shows that the standard deviation range is 0.0002 to 0.03 , so research tool could be describe as data obtained is suitable to the measurement variable.

The Kolmogorov Smirnov test is used to test distribution of normal data and if Sig value for data is greater than 0.05, this means that data is distributed naturally (Field, 2013). Table 2 shows that data distributions is normal, because Sig value to all study variables is morethan 0.05 .

Table 3 shows the changes in the average abnormal return analyzed using the t-test. This shows that there are fluctuations during the period of events taking place. If the event is depicted on a chart, it will look like the image in Figure 1.

According the calculation of the ttest in Table 4, it shows that before and after the Covid-19 is announced, the average abnormal return has a significant change, and its $t$ value significantly larger than t-table $(2,045)$. As an outbreak of non-natural disasters in the country, the market reacted to changes in average abnormal returns during the observation period, which showed the stock price level in the form of average abnormal return, which increased or decreased with the market. Form these results, it can be concluded that the study obtained H1.Table 4 shows the average change in trading volume activity that was analyzed using the t-test.

According to the calculation of the $\mathrm{t}$ statistical test in Table 4, it is shown that after announcing that the transaction volume is confirmed, the average transaction volume activity has a significant change, and the significant value of $\mathrm{t}$ count is greater than the $\mathrm{t}$-table $(2,045)$. The covid-19 outbreak is a nonnatural disaster across the country, and the market has responded to changes in the average stock trading volume activity during the observation period. This shows that in terms of trading volume, the level of stock liquidity appears as the trading volume increase or decrease. From these results, it can be concluded that the study accepted $\mathrm{H} 2$.

Table 5 reports regression analysis results of research models. F statistic value is 258,586 , and the value of $\mathrm{P}$ is 0.00 which is greates than the table values 2.045. This shows the applicability and statistical significance of model in degrees 
freedom (4/60). R-Squared is 0.952, which indicates that all explanatory variables in model explain $95.2 \%$ from the variation of the dependent variable.

Regarding the hypothesis testing, we found that average abnormal return due to Covid-19 outbreak has changed with a coefficient value of $\beta=0.976$. Calculated value $(T)$ is 16,861 , whichis greates than the table values (2.045) and is at significant level $(\mathrm{Sig}=0.00)$. As a result, first hypothesis is accepted; this shows that the announcement of the announcement of the Covid 19 outbreak as a National NonNatural Disaster after the event date was negative, causing investors to tend to sell their shares and wait and see after the announcement of the determination of the Covid-19 outbreak as a National NonNatural Disaster. We found that the average transaction volume activity has changed due to the Covid-19 outbreak, with a coefficient $\beta=0.300$. Calculated value $(\mathrm{T})$ is 11,132 , whichis greates than the table values (2.045) and is at significant level $(\mathrm{Sig}=0.278)$. As a results, the second hypothesis was accepted. This shows that with the increase in market trading volume the stock circulation has risen of fallen in terms of stock trading volume.

Ho: FEM (Fixed Effect Model) selected (if probability $>0.05)$

H1: REM (Random Effect Model) selected (if probability $<0,05$ )

According to Hausman test table, value is $1.000>0.05$. The fixed effects model is selected. Covid-19 has a major impact on the stock market.

This shows that there are fluctuations during the period of events taking place. If the event is depicted on a chart, it will look like the image in Figure 2.

Based on the completed test, in this study, researches use the hypothesa applicable to F\&t test, whichis as follow :

$$
\begin{aligned}
& \mathrm{H} 0=\text { Not significants } \\
& \mathrm{H} 1=\text { Significants }
\end{aligned}
$$

In t test or partial test, it can be seen that result of $t$ test shows that value of independent variables is $>0.05$, which mean value of Prob. $>\alpha$, then $\mathrm{H} 1$ is accepted, H0 is reject. In other words, the independent variables have no signifficant effect on dependent variable. In this F test, researcher uses Prob ( $F$ statistic) or $p$ value, where Prob (F statistic) must be compared with the significance level or $\alpha$ $(\alpha=0.05)$. Then, the results of the F test or the simultaneous test is 0.80 , which means that Prob (F-statistic) $>\alpha$ accepted by H1, $\mathrm{H} 0$ is rejected. In other words, independent variable has no significant effect on dependent variable. For R-Squared (R2) test, result obtained R-Squared ((R2)) is 0.749408, which means that dependent variable can have an impact of $74.94 \%$ $(0.749408)$ on the dependent variable. While remaining $86.54 \% \quad(0.865465)$ influenced by other variables outside study. So results of R2 test are independent variables don't significantly influence dependent greates than 0.5 then ability of independent variables don't significantly influences dependent variable. Because hypothesis in this R2 test is if value of RSquared $\left(\mathrm{R}^{2}\right)$ is greates than 0.5 then ability of independent variable is strong in explaining dependent variable is strong in explaining dependent variable, but conversly if value of $\mathrm{R}^{2}$ is less than 0.5 then ability of independent variable is not strong in explaining dependent variable. 
Table 1. Descriptive Statistic Results

\begin{tabular}{llrrrr}
\hline & $\mathrm{N}$ & \multicolumn{1}{c}{ Min } & \multicolumn{1}{c}{ Max } & \multicolumn{1}{c}{ Mean } & \multicolumn{1}{c}{ Std Deviation } \\
\hline AAR Before & 15 & -0.0429421 & -0.0821243 & -0.0548899 & 0.039564114 \\
AAR After & 15 & -0.0275791 & -0.0241219 & -0.0002677 & 0.019583674 \\
ATVA Before & 15 & 0.0016083 & 0.0045766 & 0.0027824 & 0.000912489 \\
ATVA After & 15 & 0.0022072 & 0.0028399 & 0.0023910 & 0.000239194 \\
\hline Valid & 15 & & & & \\
\hline
\end{tabular}

Source: Own calculation based on reports the JII Index

Table 2. Kolmogorov-Smirnov One-Sample Data Process Results

\begin{tabular}{|c|c|c|c|c|c|}
\hline & & $\begin{array}{l}\text { AAR } \\
\text { Before }\end{array}$ & $\begin{array}{l}\text { AAR } \\
\text { After }\end{array}$ & $\begin{array}{l}\text { ATVA } \\
\text { Before }\end{array}$ & $\begin{array}{l}\text { ATVA } \\
\text { After }\end{array}$ \\
\hline $\mathrm{N}$ & & 15 & 15 & 15 & 15 \\
\hline Normal & Mean & 0.000000 & 0.000000 & 0.000000 & 0.000000 \\
\hline Parameter $\alpha . \beta$ & $\begin{array}{l}\text { Std. } \\
\text { Deviation }\end{array}$ & 0.000954274 & 0.00439324 & 0.00038344 & 0.0007150 \\
\hline Most Extreme & Absolute & 0.173 & 0.128 & 0.161 & 0.334 \\
\hline Differences & Positive & 0.137 & 0.128 & 0.161 & 0.183 \\
\hline & Negative & -0.73 & -0.114 & -0.112 & -0.334 \\
\hline Test Statistic & & 0.173 & 0.128 & 0.161 & 0.334 \\
\hline $\begin{array}{l}\text { Asymp. Sig. } \\
\text { (2-Tailed) }\end{array}$ & & 0.200 & 0.200 & 0.200 & 0.200 \\
\hline
\end{tabular}

Source: Own calculation based on reports the JII Index

Table 3. Test Results t-test for Changes in Average Abnormal Return

\begin{tabular}{lrrrr}
\hline DAY & \multicolumn{1}{c}{ AAR } & \multicolumn{1}{c}{ CAAR } & \multicolumn{1}{c}{ t-count } & t-table \\
\hline $\mathrm{t}-15$ & -0.0602864 & -2.71289 & -7.64396 & 2.045 \\
$\mathrm{t}-14$ & 0.0273969 & 1.232859 & 3.47376 & 2.045 \\
$\mathrm{t}-13$ & -0.0622912 & -2.80311 & -7.8981 & 2.045 \\
$\mathrm{t}-12$ & -0.0175667 & -0.7905 & -2.2273 & 2.045 \\
$\mathrm{t}-11$ & 0.1184607 & 5.330733 & 15.0201 & 2.045 \\
$\mathrm{t}-10$ & 0.0720354 & 3.241591 & 9.13366 & 2.045 \\
$\mathrm{t}-9$ & -0.0534479 & -2.40515 & -6.67768 & 2.045 \\
$\mathrm{t}-8$ & 0.0458676 & 2.064044 & 5.81574 & 2.045 \\
$\mathrm{t}-7$ & -0.0223020 & -1.00359 & -2.8277 & 2.045 \\
$\mathrm{t}-6$ & 0.283829 & 1.27723 & 3.59878 & 2.045 \\
$\mathrm{t}-5$ & 0.032794 & 1.473272 & 4.1511 & 2.045 \\
$\mathrm{t}-4$ & 0.899360 & 4.047118 & 11.40335 & 2.045 \\
$\mathrm{t}-3$ & 0.0103587 & 0.46614 & 1.3134 & 2.045 \\
$\mathrm{t}-2$ & -0.0526532 & -2.36939 & -6.7611 & 2.045 \\
$\mathrm{t}-1$ & 0.006263 & 0.298184 & 0.8401 & 2.045 \\
$\mathrm{t}=0$ & -0.00507 & -0.22834 & -0.64339 & 2.045 \\
$\mathrm{t}+1$ & 0.0430491 & 1.937208 & 5.45836 & 2.045 \\
$\mathrm{t}+2$ & -0.0229671 & -1.03352 & -2.91209 & 2.045 \\
$\mathrm{t}+3$ & -0.402320 & -1.81044 & -5.10118 & 2.045 \\
$\mathrm{t}+4$ & 0.0407082 & 1.831869 & -5.16156 & 2.045 \\
$\mathrm{t}+5$ & -0.235887 & -1.06149 & -2.99091 & 2.045 \\
\hline
\end{tabular}


Table 3. Continue

\begin{tabular}{lrrrr}
\hline DAY & \multicolumn{1}{c}{ AAR } & \multicolumn{1}{c}{ CAAR } & \multicolumn{1}{c}{-count } & \multicolumn{1}{c}{-table } \\
\hline $\mathrm{t}+6$ & -0.0324891 & -1.46201 & -4.11942 & 2.045 \\
$\mathrm{t}+7$ & 0.0221814 & 0.998164 & 2.812473 & 2.045 \\
$\mathrm{t}+8$ & 0.0057317 & 0.257925 & 0.726742 & 2.045 \\
$\mathrm{t}+9$ & -0.0322807 & -1.45263 & -4.093 & 2.045 \\
$\mathrm{t}+10$ & 0.0095761 & 0.430926 & 1.214198 & 2.045 \\
$\mathrm{t}+11$ & 0.0118481 & 0.533167 & 1.5022 & 2.045 \\
$\mathrm{t}+12$ & 0.0134416 & 0.0604872 & 1.704316 & 2.045 \\
$\mathrm{t}+13$ & 0.0444914 & 2.002111 & 5.641244 & 2.045 \\
$\mathrm{t}+14$ & -0.360205 & -1.62092 & -4.56718 & 2.045 \\
$\mathrm{t}+15$ & 0.0103652 & 0.466432 & 1.314241 & 2.045 \\
\hline
\end{tabular}

Source: Own calculation based on reports the JII Index

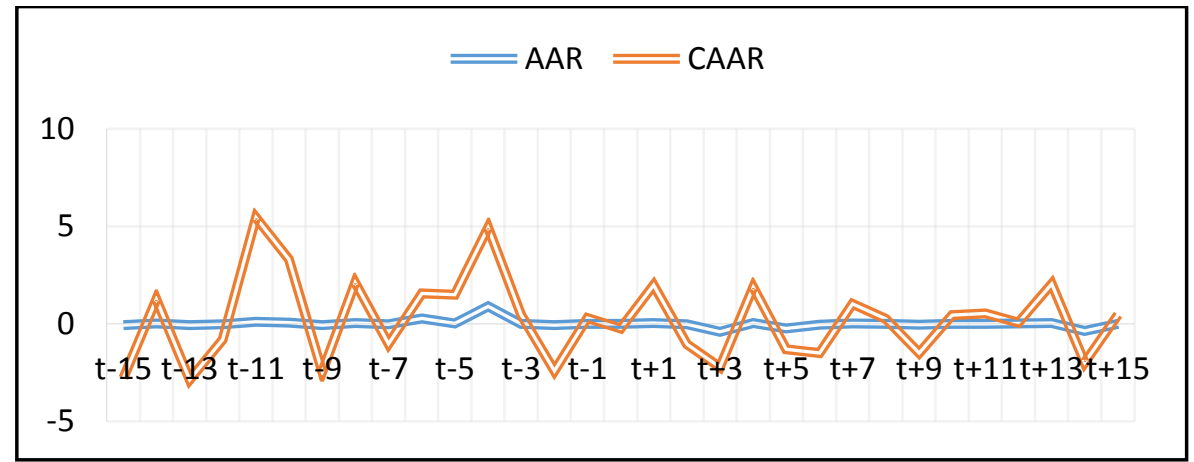

Figure 1. Graph of T Abnormal Return Test Results Source: Own calculation based on reports the JII Index

Table 4. Test Results Changes in Average Trading Volume Activity

\begin{tabular}{lllll}
\hline DAY & ATVA & CATVA & t-count & t-table \\
\hline t-15 & 0.0011374 & 0.01387042 & 8.3851 & 2,045 \\
t-14 & 0.0034183 & 0.018825157 & 25.201 & 2,045 \\
t-13 & 0.0014534 & 0.008341003 & 10.7147 & 2,045 \\
t-12 & 0.0025101 & 0.020522315 & 18.5055 & 2,045 \\
t-11 & 0.0042383 & 0.017971625 & 31.2467 & 2,045 \\
t-10 & 0.0037921 & 0.018917923 & 27.9566 & 2,045 \\
t-9 & 0.0014167 & 0.008784728 & 10.4448 & 2,045 \\
t-8 & 0.0022488 & 0.014174947 & 16.579 & 2,045 \\
t-7 & 0.0020202 & 0.012354525 & 14.8935 & 2,045 \\
t-6 & 0.0017845 & 0.011978451 & 13.1562 & 2,045 \\
t-5 & 0.0021524 & 0.0101911 & 15.8685 & 2,045 \\
t-4 & 0.0028978 & 0.01491323 & 21.3637 & 2,045 \\
t-3 & 0.0034785 & 0.016312206 & 25.6447 & 2,045 \\
t-2 & 0.0019255 & 0.01033693 & 14.1953 & 2,045 \\
t-1 & 0.0020522 & 0.008884824 & 15.1297 & 2,045 \\
\hline
\end{tabular}


Table 4. Test Results Changes in Average Trading Volume Activity

\begin{tabular}{lllll}
\hline DAY & ATVA & CATVA & $\mathrm{t}$-count & $\mathrm{t}$-table \\
\hline $\mathrm{t} 0$ & 0.001234 & 0.005934184 & 9.10432 & 2,045 \\
$\mathrm{t}+1$ & 0.0019796 & 0.006973082 & 14.5941 & 2,045 \\
$\mathrm{t}+2$ & 0.0022632 & 0.008632418 & 16.6849 & 2,045 \\
$\mathrm{t}+3$ & 0.0020353 & 0.007255459 & 15.0049 & 2,045 \\
$\mathrm{t}+4$ & 0.0022443 & 0.007454426 & 16.5456 & 2,045 \\
$\mathrm{t}+5$ & 0.0016307 & 0.006433421 & 12.0223 & 2,045 \\
$\mathrm{t}+6$ & 0.0015585 & 0.005477342 & 11.4849 & 2,045 \\
$\mathrm{t}+7$ & 0.0020384 & 0.008361763 & 15.028 & 2,045 \\
$\mathrm{t}+8$ & 0.0018857 & 0.007421851 & 13.902 & 2,045 \\
$\mathrm{t}+9$ & 0.0017236 & 0.008097749 & 12.7074 & 2,045 \\
$\mathrm{t}+10$ & 0.0014496 & 0.004108651 & 10.6872 & 2,045 \\
$\mathrm{t}+11$ & 0.0016855 & 0.004108651 & 12.4265 & 2,045 \\
$\mathrm{t}+12$ & 0.0016483 & 0.006353844 & 12.1518 & 2,045 \\
$\mathrm{t}+13$ & 0.0027181 & 0.01512073 & 20.0391 & 2,045 \\
$\mathrm{t}+14$ & 0.0016377 & 0.00936946 & 12.0739 & 2,045 \\
$\mathrm{t}+15$ & 0.0015022 & 0.007922493 & 11.0751 & 2,045 \\
\hline
\end{tabular}

Source: Own calculation based on reports the JII Index

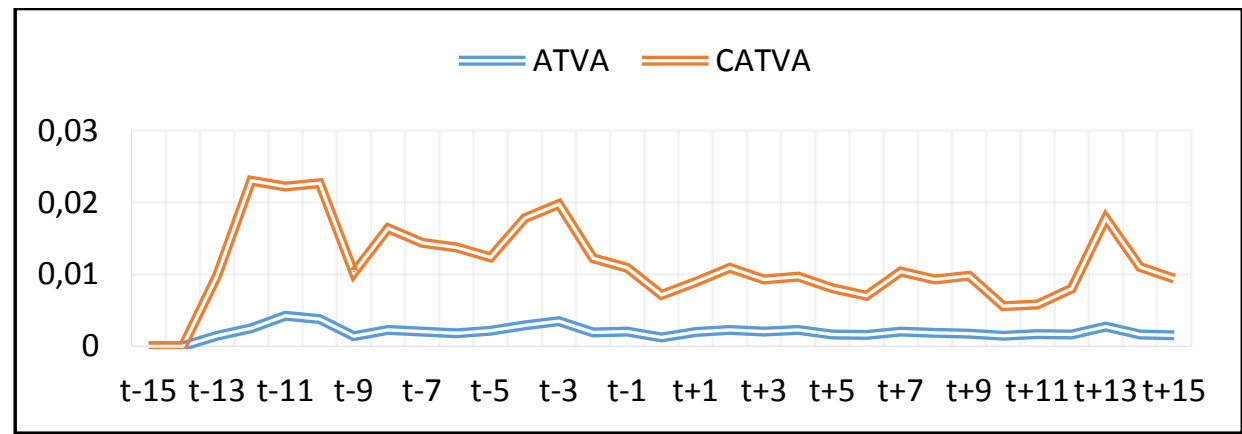

Figure 2. Test Result Graph t Average Trading Volume Activity Source: Own calculation based on reports the JII Index

Table 5 Regression Test Result

\begin{tabular}{lllllllllll}
\hline \multicolumn{1}{l}{ ANOVA } & \multicolumn{8}{c}{ Coefficient } \\
\hline R & R2 & F & F Sig & DF & Variables & B & Std & Beta & T & T Sig \\
\hline 0.976 & 0.952 & 258.586 & 0.00 & $4 / 60$ & AAR & 0.653 & 0.041 & 0.976 & 16.861 & 0.000 \\
& & & & & ATVA & 0.656 & 0.580 & 0.300 & 11.132 & 0.278
\end{tabular}

Source: Own calculation based on reports the JII Index

Table 6. Results Hausman Test

\begin{tabular}{lccc}
\hline Test Summary & Chi Square Statistic & Chi Square d.f & Probability \\
\hline Cross Section Random & 0.000000 & 4 & 1.0000 \\
\hline & Source : Data Proces (2020)
\end{tabular}


Table 7. R-Squared $\left(\mathrm{R}^{2}\right)$ Test \& T Test

\begin{tabular}{lrll}
\hline R Squared & 0.749408 & Probality (F statistic) & 0.865465 \\
Adjusted R Squared & -2.04727 & Mean Dependent Variable & 0.657466 \\
S.E of Regressions & 0.568346 & S.D Dependent Variable & 1.862325 \\
Sum Square Resid & 0.576812 & Akaike info criterion & 1.947568 \\
Log Likelihood & -8.76574 & Schwarz criterion & 2.173824 \\
F Statistic & 0.808645 & Hannan Quinn Criter & 1.974659 \\
& & Durbin Watson Statistic & 2.200456 \\
\hline
\end{tabular}

Source: Data Processed (2020)

\section{Discussion}

The results of this research are also consistent with research conducted by Bash (2019), who examined the Khassogi Events Study and the Saudi Stock Market Return. This study found that uncertain events have very significants negative impact Saudi stock return. Results of this study are also consistent with research conducted by Guo (2019), who examined the Stock Response to Environmental Policy in China. Researchers found the stock market generally reacted negatively to strict environmental regulations. Subsequent research was conducted by Shanaev (2017), who examined Regional Political Risk and the Stock Return Panel. The research resulted in the conclusion of Russian stock returns inversely proportional to regional political stability. The political process greatly contributes to the synchronization of stock returns. The next research was conducted by Kowalski (2018) who examined Impact of the Earthquake on Stock Return. Research concluded that the earthquake had a significant negative impact on stock returns. The results of this study are also in accordance with studied conducted by Mokni (2020), who examined the Varied Time Effect from Oil Price Shocks on Stock Returns and Trading Volume Activity. X. \& T. C. C. Chen (2020), examines the Empirical Investigation of Changes in Policy Uncertainty Against Stock Return and Trading Volume
Activity. Aziz (2017), examines whether Stock Return and Extreme Volume Negative Activity Volumes Are Valued in India. The object of this research is the S\&P BSE-500 Index for the period April 1999 to June 2014. Dong (2018), examines whether Global Economic Factors Encourage Emerging Asian Stock Return and Trading Volume Activity. Mo (2019), examines about Can Oil Returns Affect Stock Return and Trading Volume Activity?

\section{Economic Impact of a Virus Plague}

According the result of the panel data regression has been completed, it could be seen that values of CAR and CATVA obtained are negative, which has a significant impact on stock return. Results of this study are consistent with study from Wang (2013), which studied the spread of the SARS epidemic in Hong Kong, overcoming the economic impact, and from the consumer's point of view, the most serious negative effects appears to be serious. The short-term economic impact is strongly influenced by local consumers, tourism, and air travel related services.

Impact of Virus Outbreaks on Stock Market Performance

According results of the panel data regression has been completed, it could be seen that values of CAR and CATVA obtained are negative, which has a significant impact on stock return. Result of this study are consistent with study from 
Delisle (2014). He said that the loss caused by the SARS outbreak in 2003 was the highest in the Asian Financial crisis, with an estimated GDP value of US\$3 trillion and US\$ 2 trillion at 2004. Financial Market Equity, Nippani (2006), studied the impact SARS in China, Canada and special administraty regions of Hong Kong, Singapore, Indonesia, Philipines, Vietnam, Thailand, and concluded that SARS only affected stock markets of Vietnam and China. Del Guidice (2017), evaluate 78 region-based equity funds in African Countries from 2015-2016. The results is that the Ebola virus and the Arab Spring have severely affected flow of funds and controlled performance of funds, Expenditures, also market returns. Macciocchi (2016), studied shortterm echonomic impact of Zika Virus outbreak in Argentina, Brazil, and Mexico. The result show that each accident will produce a large negative return. Chen, M. H.; Jang, S. S.; \& Kim (2017), used event research method for study impact of the SARS outbreak on efficiency of Taiwan's hotel stocks, and found that during the SARS outbreak, the earnings and stock prices of the seven hotel stocks traded fell sharply. Chen (2018), analyzed impact of SARS epidemic on the longterm relationship with 4 Asian Stock Market. The results shows showed that the desease outbreak had a significant impact on performance of Taiwan's biotech stocks. According to Bai (2014), Baker, M.; Wirgler, J.; \& Yuan (2012), investors may be pessimistic about the prospect of in certain markets and selling these market shares under the infectious plagues.

\section{Linkages Between the Stock Market During Critical}

According to the result of the panel data regression has been completed, it could be seen that negative values of the $T$ test and $\mathrm{F}$ test obtained have a significant impact on stock return. Result of this study are consistent with study from T. Chiang (2007), which studied the daily stock returns of 9 Asian Markets from 19962003, and found that there was high correlation between the sample country in Asia in the crisis. Shu (2010), found that Southeast Asian stock markets, such as Malaysia, Vietnam, and Thailand, have the highest degree of integration with China. Lucia (2012), the global stock market becomes more and more dependent, and the crisis in 1 country will soon spread other countries. Events such as the outbreak from infectious diseases may trigger negative change investor sentiment, greatly affectly their investments decicions, also cause stocks market price to rise (Donadelli, 2016). In country that culturally more susceptible obvious action and reactions of livestock groups or country with low institutional participation and investor sentiment has a more obvious impact on the market (Zouaoui, 2011).

\section{CONCLUSIONS}

The conclusions explained above show that the events before and after the declaration of the Covid-19 outbreak as a national non-natural disaster have positive and significant impact on the average abnormal return rate of stock activity and changes in trading volume activites. In addition, the conclusion is that the best way to deal with average abnormal returns and changes in trading volume activity is to wait and see when conducting investment analysis. Because from the current situation, it could be seen from independent variables that the won't have a significants impact at stock return, thus making future lack from competition. 


\section{REFERENCES}

Abraham, M. F. (1991). Modernisasi di Dunia Ketiga Suatu Teori Umum Pembangunan. PT. Tiara Wacana Yogya.

Al-Awadhi, A. M., Alsaifi, K., Al-Awadhi, A., \& Alhammadi, S. (2020). Death and contagious infectious diseases: Impact of the COVID-19 virus on stock market returns. Journal of Behavioral and Experimental Finance, 27(1), 1-5. https://doi.org/10.1016/j.jbef.2020.10 0326

Aziz, T. \& V. A. (2017). Are Extreme Negative Return Priced in the Indian Stock Market? Journal Borsa Istanbul Review, 18(1), 1-15.

Bai, Y. (2014). Cross-border Sentiment: An Empirical Analysis on EU Stock Markets. Journal Applicant Financial Economies, 24, 259-290.

Baker, M.; Wirgler, J.; \& Yuan, Y. (2012). Global, Local, and Contagious Investor Sentiment. Journal Applicant Financial Economies, 104, 272-287.

Bash, A. \& K. A. (2019). Fear From Uncertainty: An Event Study of Khashoggi and Stock Market Returns. Journal of Behavioral and Experimental Finance, 23, 54-58.

Bernanke, B. (2010). Study Guide for Macroeconomics. Addison Wesley.

Burns, W. J. . P. \& S. (2011). Risk Perception and the Economic Crisis: A Longitudinal Study of the Trajectory of Perceived Risk. Journal Risk Analiysis, 32, 659-677.

Chen, M. H.; Jang, S. S.; \& Kim, W. G. (2017). The Impact of SARS Outbreak on Taiwanese Hotel Stock Performance: An Event-Study Approach. Journal of Hospitality Management, 26, 200-212.
Chen, M.-P. et al. (2018). Did The SARS Epidemic Weaken the Integration of Asian Stock Markets? Evidence from Smooth Time-Varying Cointegratio Analysis. Journal Economic Research, 31(1), 08-926. https://doi.org/https://doi.org/10.1080/ 1331677X.2018.1456354

Chen, M., Shawn, S., \& Gon, W. (2007). The impact of the SARS outbreak on Taiwanese hotel stock performance : An event-study approach. 26(November 2002), 200-212. https://doi.org/10.1016/j.ijhm.2005.11 .004

Chen, X. \& T. C. C. (2020). Empirical Investigation of Changes in Policy Uncertainty on Stock ReturnsEvidence from China's Market. Journal Research in International Business and FInance, 53(1), 12-15.

Chiang; Bang Nam Jeon; \& Humin Li T. C. (2007). Dynamic Correlation Analysis of Financial Contagion: Evidence from Asia Markets. Journal Industrial Monitoring Finance, 26, 1206-1228.

Del Guidice, A. . \& P. (2017). The Impact of The Arab Saudi Spring and the Ebola Outbreak on African Equity Mutual Fund Investor Decisions. Journal International Business Finance, 41, 600-612.

Delisle, J. (2014). SARS: Greater China and the Patologies of Globalization and Transition. Journal Orbis, 47, 587-604.

Donadelli, M. . \& P. G. (2016). Labor Market Dynamics, Endogenous Growth, and Assets Prices. Journla Economics Letters, 143, 32-37.

Engelberg, J.; \& Parsons, C. (2011). The Causal Impact of Media in Financial Markets. Journal Finance, 66, 67-97. 
Field, A. (2013). Discovering Statistics Using IBM SPSS Statistics (4th ed.). SAGE Publications.

Gatot, S. (2014). Transaksi Bisnis Saham dan Penyelesaian Sengketa Melalui Pengadilan. Kencana.

Goodell, J. W. (2020). COVID-19 and finance: Agendas for future research. Finance Research Letters, 35, 1-5. https://doi.org/10.1016/j.frl.2020.101 512

Gorton, G. (2009). The Panic of 2007. Yale School of Management and NBER.

Hartono, J. (2015). Teori Portofolio dan Analisis Investasi (Kesembilan). BPFE.

Hendriswari, I. (2017). Pengaruh Wabah Virus Flu Burung Terhadap Return Saham Perusahaan Peternakan Ayam di Bursa Efek Jakarta. Universitas Sanata Dharma.

Ichev, R.; \& Marinic, M. (2017). Stock Prices and Geographic Proximity of Information: Evidence from the Ebola Outbreak. Journal International Review of Financial Analysis, 56, 153-166.

Kowalski, O. \& P. S. (2018). Stock Market Response to Potash Mine Disasters. Journal of Comodity Markets.

Laing, T. (2020). The economic impact of the Coronavirus 2019 (Covid-2019): Implications for the mining industry. The Extractive Industries and Society, $7(2), 580-582$.

https://doi.org/10.1016/j.exis.2020.04. 003

Liu, H., Manzoor, A., Wang, C., Zhang, L., \& Manzoor, Z. (2020). The COVID-19 Outbreak and A ff ected Countries Stock Markets Response. International Journal of Environmental Research and Public Health, 17(8), 1-19.
Liu, H. Y. (2020). The Importance of Trust Distance on Stock Market Correlation: Evidence From Emerging Economics. Journal Borsa Istanbul Review, 20, 37-47.

Lu, X. F. \& L. K. K. (2012). Relationship Between Stock Indices and Inventors Sentiment Index in Chinese Financial Market. Journal System Engineering Theory Practice, 32, 621-629.

Lucia, M. \& B. A.-O. (2012). The Current Global Finance Crisis: Do An Asian Stock Markets Show Contagion Or Independence Effects? Journal of Asian Economic, 23, 616-628.

Macciocchi, D. (2016). Short-term Economic Impact of the Zika Virus Outbreak. Journal New Microbiologica, 39, 287-289.

Mengmeng, G. (2019). Stock Market Response to Envirometal Policies: Evidence From Heavily Polluting Firms in China. Journal Economic Modelling, 86(C), 306-316.

Mo, X. Z. S. \& L. Y. (2019). Can The Skewness of Oil Returns Affect Stock Returns? Evidence from China's AShare Markets. North American Journal of Economics and Finance, 50, 101042.

Mokni, K. (2020). Time-Varying Effect of Oil Price Shocks on The Stock Market Returns: Evidence from OilImporting and Oil-Exporting Countries. Journal Energy Reports, 6, 605-619.

Nicola, M., Alsafi, Z., Sohrabi, C., Kerwan, A., \& Al-jabir, A. (2020). Title : The Socio-Economic Implications of the Coronavirus and COVID-. In International Journal of Surgery. IJS Publishing Group Ltd. https://doi.org/10.1016/j.ijsu.2020.04. 018 
Nippani, S. \& K. M. W. (2006). SARS: A Non-Event for Affected Countries Stock Markets? Journal Applied Financial Economics, 14(15), 11051110.

Rusdin. (2016). Pasar Modal: Teori, Masalah, dan Kebijakan Dalam Praktik. Alfabeta.

Shanaev, S. \& B. G. (2017). Is All Politics Local? Regional Political Risk in Rusia and The Panel of Stock Returns. Journal Behavioral and Experimental Finance, 174, 70-82.

Shu, H. C. (2010). Investor Mood and Financial Markets. Journal Economic Behavioral Organization, 76, 267282.

Tachibana, M. (2018). Relationship Between Stock and Currency Markets Conditional on the US Stock Returns: A Vine Copula Approach. Journal of Multifinance Management, 46, 75106.

Taleb, N. N. (2007). The Black Swan: The impact of the high improbable. Random House.

Tjiptono, D. dan H. M. F. (2011). Pasar Modal di Indonesia (3rd ed.). Salemba Empat.

Wang, Y. H. Y. F. J. \& C. L. J. (2013). An Inventor's Perspecitve on Infectious Diseases and Their Influence on Market Behaviour. Journal Business Economic Management, 14, 112-127.

Yoon, D. X. \& S.-M. (2018). What Global Economic Factors Drive Emerging Asian Stock Market Return? Evidence From a Dinamic Model Averaging Approach. Journal Economic Modelling, 77(1), 204-215.
Zhang, D., Hu, M., \& Ji, Q. (2020). Financial markets under the global pandemic of COVID-19. Finance Research Letters, 36, 1-6. https://doi.org/10.1016/j.frl.2020.101 528

Zouaoui, M. (2011). How Does Investor Sentiment Affect Stock Market Crises? Evidence from Panel Data. Journal The Financial Review, 46(4), 723-747. 